\title{
Ice blue
}

\section{Escape from your cells.}

\section{Paula R. Stiles}

Doing the Antarctic cryosphere slides is addictive. I take one out and click it into my headset. It's from Lake Vostok, two miles under the ice at the bottom of the world. Instantly, I'm in blue darkness. I'm a tiny single-celled organism, made up of protoplasm and primitive cellular structures - nucleus, mitochondria, cytoplasm, cell wall. I extend the latter into a tentacle to explore turgid water and flakes of ice that feel like icebergs to my microscopic size. I give off a small glow that illuminates my surroundings. I see some other glows far off. Not sure if they're friend or foe, but I'm hungry, so I go after them.

"Jethro ... hey, Jethro, wake up."

Blinking automatically clicks me out of the slide. The slide ejects itself, sticking out of the side of my headset. I remove it and lay it on the table next to me. I look up at my labmate, Sandra, still blinking. My eyes feel dry.

"What?" I say. It takes time to gear up from a singlecelled organism to one with too many cells to count.

"You all right?" Sandra asks.

"Sure, fine." I sit up and start typing my observations into my computer. You can plug a slide into a machine and get all the data, but the human brain is still the best way to filter that experience. One good thing about living on the Moon is that it makes it easier to feel as if you're under water. One-sixth of Earth gravity is like that. I undo my headset and gently push myself to my feet.

"You've been acting funny ever since those new slides came in from Antarctica. I have to tell you, Jethro, I'm a little worried."

"I don't see why. I'm just doing my job."

She shakes her head. As I look around, I try to see blues in the colour scheme of the lab. But everything is orange and pink, the better to keep us happy and energized. "It's more than a job for you," she says. "You're getting lost in there."

I shrug that off. "Would you rather I did an oxygen high or went outside without a spacesuit? Seems to me that doing my job

and enjoying it isn't the worst thing out there."

"Yes, but you're really hogging the slides." Now that I'm getting a closer look at her, she doesn't seem so much obsessed with the rules as something else. In fact, she looks downright pinched, like an oxygen addict. Oxygen is rationed here on the Moon. You have to pay for it and boy, is it expensive. The poor (the government likes to call them "more frugal") are chronically anoxic.

She glances towards the slide lying innocently on

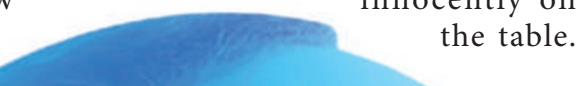

